\title{
Det nye billede
}

\section{Kor 15,49 og forvandlingsmotivet i romersk visualitet}

\author{
Seniorforsker, mag.art., cand.theol. \\ Thomas Lederballe Pedersen, Statens Museum for Kunst
}

\begin{abstract}
Discussing the scenario of future resurrection in 1 Cor. 15, Paul touches on the visual aspects of the bodily transformation which he claims will take place as a part of eschatological fulfilment. The concept of image plays a crucial role in this transformation as he believes the resurrected body will be shaped according to a "heavenly" exemplar, which he refers to as an image. Using examples drawn from Roman visual culture, both visual and textual, the article describes what type of image Paul's Corinthian readers would have been inclined to think of in connection with a discussion of bodily transformation such as the one imagined by Paul.
\end{abstract}

Keywords: First Corinthians - Visual Studies - Roman Sculpture Ovid - Metamorphosis

\section{Billede som nøgleord i Første Korintherbrev}

To gange i Første Korintherbrev bruger Paulus ordet billede ( $\varepsilon ı \kappa \omega ́ v)$ for at anskueliggøre sine overvejelser. Første gang sker det i forbindelse med diskussionen af kvinders liturgiske hovedbeklædning $(11,7)$, anden gang $(15,49)$ som led i diskussionen af kroppens forvandling ved opstandelsen. Omstændighederne for anvendelsen af ordet er forskellige, men dets optræden rejser spørgsmålet om dets forbindelse til periodens billedbegreb, som grundlæggende opfatter billedet som en efterligning af virkeligheden. ${ }^{1}$

I forbindelse med Paulus' insisteren på kroppens opstandelse som eskatologisk fuldbyrdelse tilskyndes han i brevets afsluttende del til at gøre nærmere rede for den opstandne krops udseende. ${ }^{2}$ Ved at gøre

1. Et grundtræk ved det romerske billedbegreb, uanset dets historiske forskydninger, som er beskrevet i Raimund Daut, Imago. Untersuchungen zum Bildbegriff der Römer BKAW, Reihe 2, 56 (Heidelberg: Carl Winter 1975).

2. Min fortolkning i det følgende tager især udgangspunkt i to eksegetiske arbejder af Dale B. Martin og Troels Engberg-Pedersen. Martin har foreslået, at 1 Kor som helhed skal læses som korrektion af en socio-kulturel korintisk elites kropsforståelse, og at kap. 15 i overensstemmelse hermed præciserer indholdet af forestillingen om de dødes opstandelse, sådan at den kan integreres i somatologi af den art, man f.eks. finder i stoisk kosmologi. Med denne tolkning afviser han Anthony C. Thiseltons 
brug af et ordspil på navnet Adams rod i det hebraiske ord for jord (אדמה), beskriver han kroppens forvandling som en erstatning af det første menneske, Adams billede med Kristus' billede: "De, som er af jord, er sådan som ham af jord, og de himmelske også sådan som den himmelske, og således som vi har båret den jordiskes billede, skal vi også bære den himmelskes billede" (1 Kor 15,48f). ${ }^{3}$

Forklaringen falder i forbindelse med besvarelsen af spørgsmål om kroppens opstandelse: Hvordan finder den sted, og hvordan tager den sig ud? For en umiddelbar betragtning forklarer han det dunkle ved hjælp af det dunkle, for selv om han her - og i de omgivende passager - kredser om den opstandne krops egenskaber, fremkommer han ikke med nogen nærmere beskrivelse af det nye billede, som skal erstatte det gamle. Forståelsen af dets udseende må derfor have forudsat visuelle vaner, på baggrund af hvilke vendingen "den himmelskes billede" har fremmanet bestemte forestillinger hos læseren, som har kunnet tilføre den indholdsmæssig præcision. Jeg skal i det følgende beskrive disse vaner. ${ }^{4}$

\section{Visualitet og visuel kultur som metodisk greb}

En eksegetisk kontekstualisering, der som den følgende drejer sig om den bibelske teksts forhold til visuelle vaner, trækker på indsigter, der stammer fra nyere kunsthistories udvikling af begreber om visualitet og visuel kultur. I de senere årtier har der fundet en "eksplosion" sted inden for studiet af nytestamentlige teksters sammenhæng med visuelle artefakter fra antikken. ${ }^{5}$ Studiet af Paulus' breve ud-

hypotese om, at brevets ærinde er at korrigere "over-realiseret" eskatologi i den korintiske menighed, og han placerer dermed kropsforestillinger i centrum af brevets anliggende på en måde, som siden er blevet kvalificeret af Troels Engberg-Pedersen med dennes henledning af opmærksomheden på kropslig transformation som emne i det paulinske brevkorpus som helhed. Se Dale B. Martin, The Corinthian Body (New Haven \& London: Yale University Press 1995), xv samt 105ff. Thiseltons læsning lanceredes i "Realized Eschatology at Corinth", NTS 24, 4 (1978), 510-26. Endvidere Troels Engberg-Pedersen, Cosmology and Self in the Apostle Paul: The Material Spirit (Oxford: Oxford University Press 2010).

3. Alle oversættelser fra antikke tekster i det følgende er mine egne.

4. På en måde som minder om Martins indkredsning af de antikke forestillinger om kroppen, på baggrund af hvilke Paulus' udsagn om kroppen i 1 Kor har været meningsfulde (Martin 1995: xiii). Hvor Martins kilder til datidige kropsforestillinger er skriftlige, vil mine kilder delvist være visuelle.

5. "Eksplosion": se Vernon K. Robbins, Walter S. Melion \& Roy R. Jeal, "Introduction", The Art of Visual Exegesis. Rhetoric, Texts, Images, red. V.K. Robbins, W.S. Melion \& R.R. Jeal (Atlanta: SBL Press 2017), 1-9 (2). 
gør ingen undtagelse, men brugen af antikke billeder i forbindelse med denne eksegese begrænser sig hovedsageligt til inddragelse af deres ikonografi, f.eks. i forbindelse med udlægning af semantiske forskydninger ved strukturalistiske udlægninger af brevenes sociopolitiske koder. ${ }^{6}$ I denne sammenhæng udgør J.M.F. Heaths bidrag en undtagelse, idet hun snarere end at beskæftige sig med billedernes konventionelle betydninger har rettet opmærksomheden mod synsvaner for at beskrive visuel oplevelse og billede som emner i Paulus' breve. $^{7}$ Hun interesserer sig ikke for kunstværker som betegnere og som fremstillingsformer, men beskriver i forlængelse af nyere britiske og amerikanske kunsthistorikeres udredning af historisk betingede synsmåder forholdet mellem antik visuel praksis på den ene side og Paulus' skildringer af visuelle forhold på den anden. ${ }^{8}$ Hvor hun altså gør brug af den kunsthistoriske nyorientering, der har fundet sted siden 1980'erne i en gradvis erstatning af ikonografiske og semiotiske metoder med visualitetshistoriografiske, udelader hendes arbejde imidlertid sammenhængen mellem billedprodukter og visuelle vaner, fordi hun opfatter antikke tekster som mere relevante kilder til periodens visualitet (Heath 2013: 36).

Den følgende udlægning af 1 Kor 15,49 udreder visuelle vaner ved hjælp af både visuelle og skriftlige kilder. Hvad fortæller de pågældende kilder om de synsmåder, som har gjort Paulus' udsagn om de himmelske billede meningsfuldt for hans læsere?

6. Det gælder f.eks. Brigitte Kahl, "The Galatian Suicide and the Transbinary Semiotics of Christ Crucified”, (Robbins, Melion \& Jeal 2017), 195-240 og Davina C. Lopez, Apostle to the Conquered. Reimagining Paul's Mission (Minneapolis: Fortress Press 2010).

7. J.M.F. Heath, Paul's Visual Piety. The Metamorphosis of the Beholder (Oxford: Oxford University Press 2013).

8. Jeg anvender her begrebet "visuel vane/praksis" til at betegne det forskningsfelt, som blev åbnet med visuel kultur-studierne af især Michael Baxandall i hans korte, men indflydelsesrige bog Painting and Experience in Fifteenth-Century Italy (Oxford: Oxford University Press 1974). Forskningsfeltet er siden blevet beriget med såkaldte visualitetsstudier, repræsenteret af værker som David Freedberg, The Power of Images. Studies in the History and Theory of Response (Chicago: University of Chicago Press 1989) og W.J.T Mitchells artikel "What do Pictures Really Want?", October, 77, 1996, 71-82. Fælles for disse bidrag er interessen for billeders samspil med betragteren, dvs. visuelle færdigheder (f.eks. indsigt i geometri) eller disposition for tilegnelse (f.eks. begær eller fromhed), som bibringer billedoplevelsen en situationsspecifik karakter, der ikke kan reduceres til spørgsmål om motivgenkendelse eller betydningsafkodning. 
Kroppens forvandling og forvandlingens kosmologiske forudsætninger hos Paulus

Det står altså klart, at Paulus mener, at de kristne skal undergå en legemlig forvandling. Han illustrerer forskellen på den nuværende og den fremtidige krop ved dels at drage to paralleller til forskellen på legemer inden for henholdsvis plante- og dyreliv, dels at pege på forskellen på jordens og himlens legemer som eksemplarisk for forskellen på henholdsvis det nuværende og det opstandne legeme. Ved sammenligningen med planter jævnføres det nuværende, dødelige legeme med et frø, som placeres i jorden og forgår, men derved omdannes til en plante og antager en anden legemlig beskaffenhed (v. 37-38). På samme måde som planten er forskellig fra sit frø, lader Gud alt "kød" ( $\sigma \alpha ́ \rho \xi)$ have forskellig karakter: Mennesket og dyrerigets arter har hver sin udformning. Med termen "kød" introducerer Paulus her desuden sit begreb for den type legeme, som i menneskets tilfælde endnu ikke har antaget Kristus' billede (cf. v. 50). Ligesom der er forskel på arter af kød, består der en kategorial forskel på jordiske legemer, altså varianter af kød, på den ene side og himmelske legemer på den anden, idet denne forskel for menneskets vedkommende svarer til forskellen på henholdsvis det jordiske individ (Adam), hvis billede læserne bærer, og det himmelske menneske, hvis billede de skal komme til at bære. I v. 51-52 præciserer Paulus, at alle - både levende og døde kristne - skal forandres ved Kristus' parusi, sådan at alt "kød og blod" undergår samme metamorfose.

Som Troels Engberg-Pedersen har anført, er Paulus' sondringer mellem forskellige typer legemer, deres hierarki og placering i verdensaltet $\mathrm{i}$ overensstemmelse med stoisk kosmologi som den, man finder i Ciceros De natura deorum (Engberg-Pedersen 2010: 27-32). Ifølge Cicero befinder himmellegemerne - solen, månen og stjernerne - sig som ild yderst i verdens sfæriske helhed, hvorfra de som det ædleste element nærer verdens andre elementer. Dette element spreder sig fra den såkaldte ater nedad i kosmos, hvor det forædler luft, jord og vand og frembringer vækst. ${ }^{9}$ Paulus' skildring af den kosmiske orden svarer til dette verdensbillede. Hans fremstilling af opstandelsen følger derfor de samme principper: Ved opstandelsen forvandles en jordisk krop til en himmelsk, og denne forvandling er en forædling af den opstandne. I Paulus' kosmologi hedder den for-

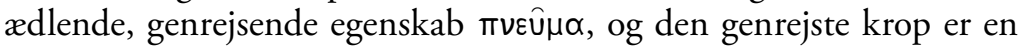
pneumatisk krop (v. 44). Denne krop svarer til himmellegemerne, for

9. Cicero, De natura deorum. Academica LCL 268, overs. H. Rackham (London: William Heinemann 1972), II,XV. 
netop deres materiale, pneuma, er dens særkende: ligesom sol, måne og stjerner kendetegnes ved deres (lysende) glans ( $\left.\delta o^{\prime} \xi \alpha\right)$, oprejses den

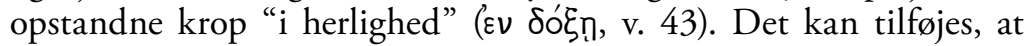
eftersom himmellegemerne som manifestationer af æterens ild ifølge Cicero behersker verden og bevirker dens frembringelser, identificeres disse himmellegemer med mytologiens guder og legemliggør over for mennesker de godartede magter, som styrer verden. Omvendt følger guddommeliggørelsen af mennesker som Herkules og Romulus samme logik, fordi de gennem deres overmenneskelige præstationer har vist, at de er manifestationer af æterens guddommelige kraft (Cicero 1972, II,XXIII).

\section{Forvandlingen fra kød til pneumatisk krop}

Som helhed kan kapitel 15 læses som redegørelse for en kropslig forandring, som skal finde sted i nær fremtid. I v. 31 pointerer Paulus dog, at denne proces allerede foregår: "Dagligt dør jeg ved stolthed over jer, brødre, den som jeg har i Jesus Kristus, vor Herre." Med dette udsagn markerer han, at forandringen fra kødeligt til åndeligt legeme er påbegyndt, da han jo herefter forklarer, at antagelsen af det åndelige legeme forudsætter det kødelige legemes bortgang.

Troels Engberg-Pedersens analyse af Paulus' redegørelse for den pneumatiske krops tilblivelse belyser, hvordan Paulus' bemærkning i v. $31 \mathrm{om}$ sin egen hensygnen er integreret i hans eskatologiske forvandlingsforståelse. Tanken formuleres nærmest programmatisk i 2 Kor 4,10-11, hvor Paulus perspektiverer sine trængsler: "idet vi altid bærer rundt på Jesus' dødelse i kroppen, for at også Jesus' liv kan komme til syne i vores krop. For vi, de levende, overgives altid til døden for Jesus' skyld, for at Jesus' liv kan komme til syne i vores dødelige kød" (2 Kor 4,10f). Denne beskrivelse optræder efter konstateringen af, at Paulus - og hans trosfæller - har modtaget en kraft

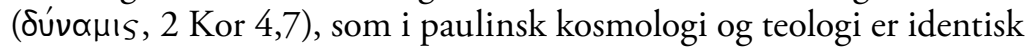

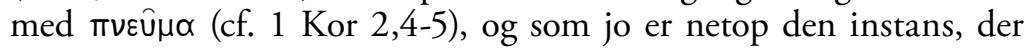
bevirker den kropslige forandring til en pneumatisk krop ved opstandelsen. Den dødsproces, som Paulus berører i 1 Kor 15,31, og som han skildrer som kødets synlige afgåen ved døden under den pneumatiske krops tilsynekomst i 2 Kor 4,10-11, stemmer således overens med den forvandling, som opstandelsens pneumatiske krops antagelse af det himmelske menneske, Kristus' billede udgør: "with the arrival of the pneuma, the body of flesh and blood is at one and the same time undergoing two opposed processes: dying (as flesh and 
blood) and coming to life (as a pneumatic body)" (Engberg-Pedersen 2010, 48). Forestillingen om omdannelsen til et pneumatisk legeme, som har del i himmellegemernes materiale, dukker igen op i Fil 3,21, hvor forandringen beskrives som visuelt manifest; en omformning, hvis kendetegn er himmellegemets glans ( $\left.\delta \delta^{\prime} \xi \alpha\right)$ og et forandret ud-

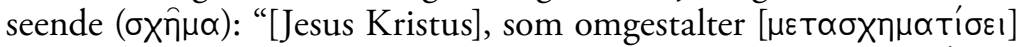

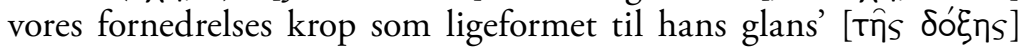
krop i overensstemmelse med kraften i hans evne til at underlægge sig alting" (Fil 3,21). Paulus taler i nutid om en forandring, som er aktuel: Der foregår en synlig forandring, også selv om den ikke beskrives. ${ }^{10}$

At dømme efter et par passager i Paulus' breve har denne forvandlingsproces været til stede i hans forkyndelse som en "kropslig praksis”, dvs. en anskueliggørelse af den eskatologiske situation gennem hans egen krops fremtoning. I Galaterbrevet optræder der flere henvisninger til en sådan sammenhæng mellem forkyndelsens indhold og Paulus' egen fremtræden. Han nævner sin egen "svaghed i kødet” som anledning til forkyndelsen hos galaterne $(4,13)$, og han antyder en sammenhæng mellem sin forkyndelses indhold og sit kropslige udtryk, når han forklarer, at Kristus er blevet "tegnet op" som korsfæstet for øjnene af dem $(3,1)$. Galaterne må i hvert fald have brugt øjnene i forbindelse med forkyndelsen, for de havde gerne revet dem ud og givet dem til ham $(4,15)$, og han insisterer på sit kødelige legemes synlige bortgang ved brevets slutning, hvor han påstår at bære "Jesus' sårmærker” på sin krop. Eftersom modtagelsen af forkyndelsens indhold også var modtagelsen af ånden (3,2-5), må galaterne have set andet end kødets svaghed i Paulus, anfører Troels Engberg-Pedersen: "What did they see? We know the answer if we may extrapolate from all the other passages where Paul places the pneuma in his own dying body. What they saw will have been the resurrection glory of the pneuma” (Engberg-Pedersen 2010, 197).

Paulus' fremhæver også i 1 Kor sin "svaghed", "skælven" og "frygt", dvs. ringe eller forkastelige aspekter ved sin fremtoning ved ankomsten hos korinterne $(2,3)$, og han udvider sin selvfremstilling til at omfatte alle apostle, når han sammenligner dem med fangerne i et triumftog, "For jeg synes, at Gud har fremvist os, apostlene, som yderste, ligesom dem, som er bestemt til døden, fordi vi er blevet et skuespil for verden og engle og mennesker" $(4,9)$. Ifølge Dale B. Martin er der en sammenhæng mellem Paulus' fremhævelse af sin og sine tilhængeres undseelige eller foragtelige statur i brevets første fire

10. Troels Engberg-Pedersen, "Complete and Incomplete Transformation in Paul - a Philosophical Reading of Paul on Body and Spirit", Metamorphoses, Resurrection, Body and Transformative Practice, red. Turid Karlsen Seim \& Jorunn Økland (Berlin \& New York: Walter de Gruyter 2009), 123-46 
kapitler på den ene side og den radikale omvending af gængse sociale kulturelle hierarkier som de pågældende kapitlers grundtema på den anden. ${ }^{11}$ I det uværdige findes forudsætningen for transformationen ved pneuma (cf. 3,1-3).

Når Paulus i 1 Kor 15,31 taler om sin påbegyndte død, er der altså tale om en død, som allerede hans indledende forkyndelse blandt korinterne ifølge kap. 1-4 har indvarslet, og som han i kapitel 15 forklarer skal fuldbyrdes ved opstandelsen, hvor det afdøde kød erstattes fuldstændig af den pneumatiske krop, Kristus' himmelske legemes billede.

Princeps' to legemer: Den tvedelte krop i Augustus Prima Porta

Paulus' beskrivelse af det døende legeme, repræsenteret ved Jesus og hans egen martrede person, er betydeligt mere malende og præcis end hans omtale af den pneumatiske krop og af "den himmelskes billede." Hvad disse angår, nøjes han med at illustrere sin pointe ved at omtale forskellen på frø og plante eller på jordiske og himmelske legemer. Hvordan korinterne kan have forestillet sig forholdet mellem de to alternative legemer antydes derfor snarere af konventioner, som knytter sig til visuelle produkter fra den tidlige kejsertid. F.eks. har Florence Dupont i en artikel om den romerske kejsers ligfærd og apoteose fra og med Augustus' (år 14 e.Kr) til og med Septimius Severus' (år 217 e.Kr.) hæftet sig ved dette begravelsesrituals to led: Efter en kremering af kejserens urene lig (ossa) blev der gennemført en funus imaginarium, hvor hans imago, som blev anset for hans krop på lige fod med ossa, ligeledes blev brændt. Imago var en voksfigur, som gengav kejseren. Først med den kejserlige imagos ligfærd kunne kejserens apoteose finde sted, for i modsætning til ossa var imago, kejserens "anden" krop, ikke behæftet med et ligs konventionelle urenhed. ${ }^{12}$

Det pågældende rituals visuelle tvedeling af kejserens legeme er analog med den, man finder i visse romerske kejserfremstillinger, og som optræder eksemplarisk i Augustus Prima Porta fra tiden efter Augustus' parthiske felttog i 20 f.Kr. (fig. 1). Statuen afspejler en tvedeling ved opfattelsen af Augustus' person under principatet

11. Martin argumenterer for, at denne inversion af socio-kulturel høj- og lavstatus bl.a. repræsenteres ved egenskaber, der knytter sig til kroppens fremtoning. Martin (1995), f.eks. 54-55.

12. Florence Dupont, "The Emperor-God's Other Body", Fragments for a History of the Human Body, overs. Brian Massuni, red. Michel Feher, Ramona Nadaff \& Nadia Tazi (New York: Zone 1989), 197-419 (403-4). 
efter borgerkrigens ophør i 27 f.Kr. Som Paul Zanker har påvist, blev Augustus gennem en suggestiv og alluderende billedkunst iscenesat som hovedfigur i en mytologi, som kredsede om statens guddommeligt sanktionerede status. Der kan iagttages to særskilte tendenser i fremstillingen af denne figur: På den ene side søgte Augustus at fremmane et billede af sig selv som princeps, førstemand blandt senatets medlemmer, og som triumfator, dvs. en traditionel imperiebygger. På den anden side opdyrkedes i en stadigt mere intensiv personkult, inden for hvilken han fik tilnavnet "Augustus" (den ophøjede), en figur, som var udstyret med en romersk guds konventionelle træk. ${ }^{13}$

I Augustus Prima Porta registreres begge figurer. Der er på den ene side tale om et portræt, for ansigtet bærer lighed med den portrætterede Augustus som individ og triumfator. Figuren bar oprindeligt en romersk standard, som partherne ved deres overgivelse havde leveret tilbage til romerne, og som også ses blive overrakt til en romersk soldat af en parther midt på harniskets brystpanser. Figuren forestiller altså et jordisk individ og fortæller om en historisk begivenhed. Men samtidig træder en ophøjet og guddommelig skikkelse frem i figuren. Den er udført i en klassisk stil og citerer et kanonisk værk i klassisk, græsk kunst, Polyklets Spydbereren (fig. 2). Selv ansigtet er gengivet med disse stiltræk, og figuren forlenes dermed med skønhedsidealer, som blev anset for tidløse. I overensstemmelse med konventionerne for fremstillinger af guder er Augustus barfodet, og hans guddommelige aner antydes af delfinen og Eros ved hans højre fod, allusioner til den juliske urmoder, Venus. Parthertriumfen på brystpanserets midte indskriver sig i en kosmisk helhed (fig. 3): Nederst frembringer Tellus sine gaver, symboliseret ved et overflødighedshorn, mens Apollon og Diana (henholdsvis forbundet med sol og måne) flankerer hende. På hver side af parther-overgivelsen ses kvindelige personifikationer af folkeslag, som romerne har undertvunget, og øverst ses Caelus med himmelteltet, solguden med sin vogn og månegudinden bag Aurora. Med andre ord indfældes parthertriumfen i et velordnet, mytisk kosmos (Zanker 1989, 194-5). Det er imidlertid værd at bemærke, at denne verdensorden bæres frem af Augustus' ophøjede, klassiske krop, som dermed kommer til at udgøre det fremstillede kosmos' grundlag - i både bogstavelig og metaforisk forstand. Med Zankers præcise formulering "inkorporerer" Augustus her den kosmiske orden, som imperiet indgår i: "Der Götterspross garantiert die Ordnung der Welt durch seine blosse Existenz. Dank seiner Ahnen verkörpert sich in ihm das Einvernehmen zwischen Staat und Göttern”

13. Paul Zanker, Augustus und die Macht der Bilder (München: Verlag C.H. Beck 1989), 103-4. 


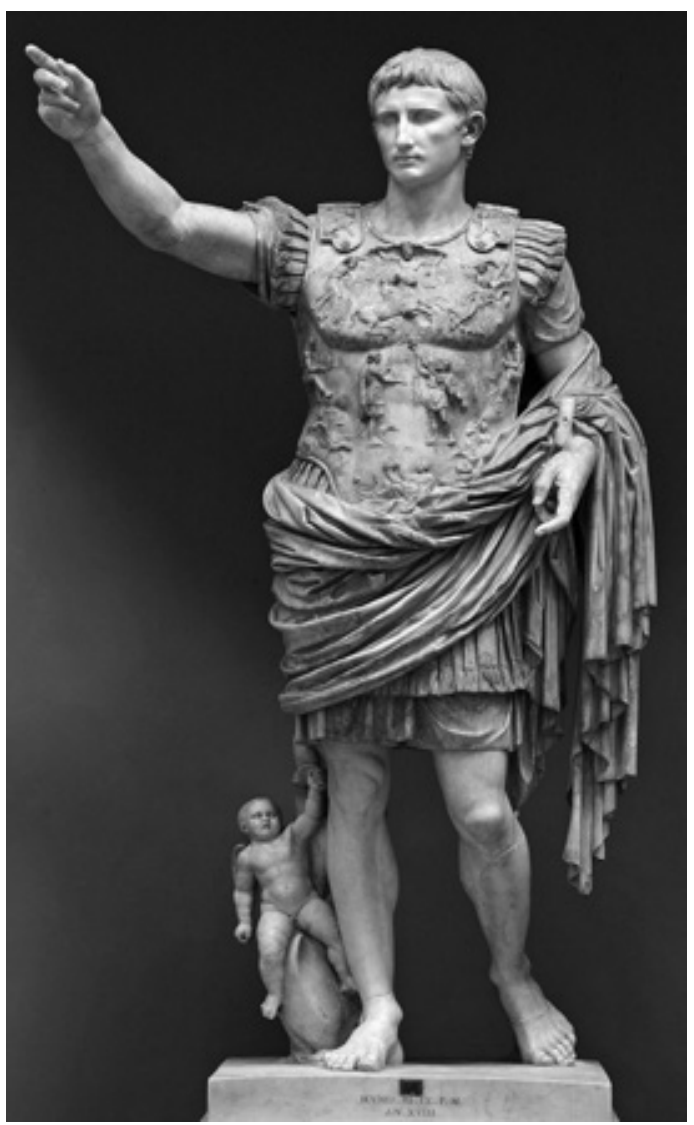

Fig. 1. Augustus Prima Porta. Første årtier af 1. århundrede. Vatikan-museet, Rom.

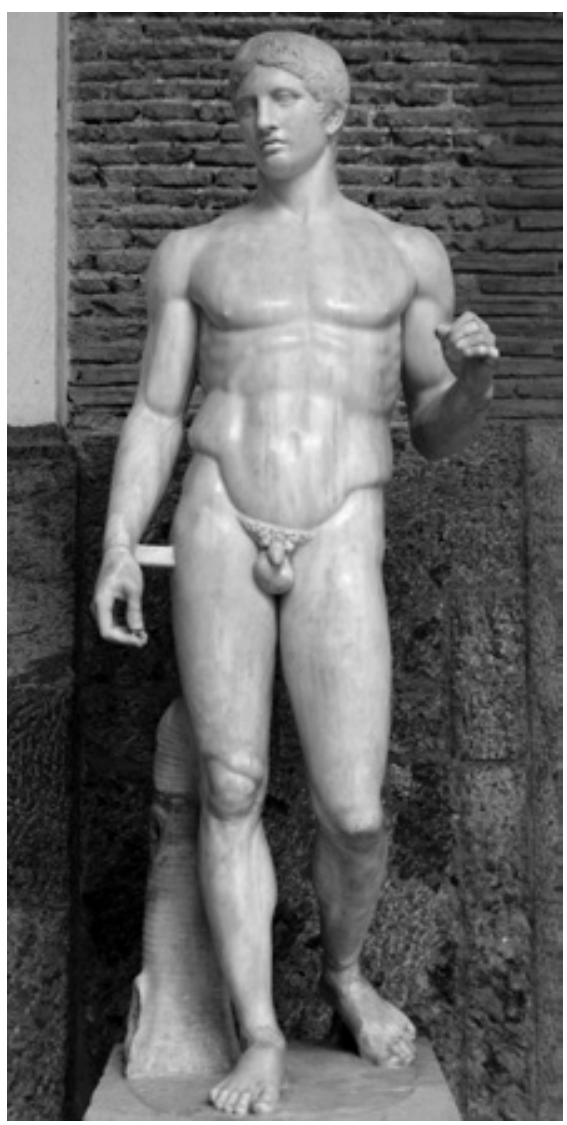

Fig. 3. Polyklet, Spydbareren. Romersk kopi efter græsk skulptur fra 5. årh. f.Kr. Museo Archeologico Nazionale, Napoli. 


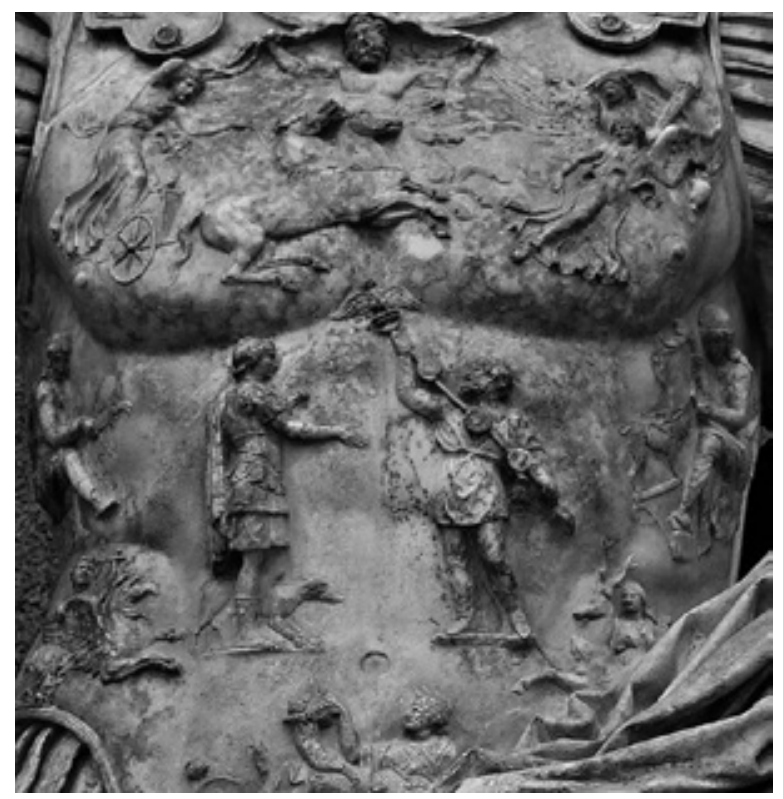

Fig. 2. Detalje af figur 1.

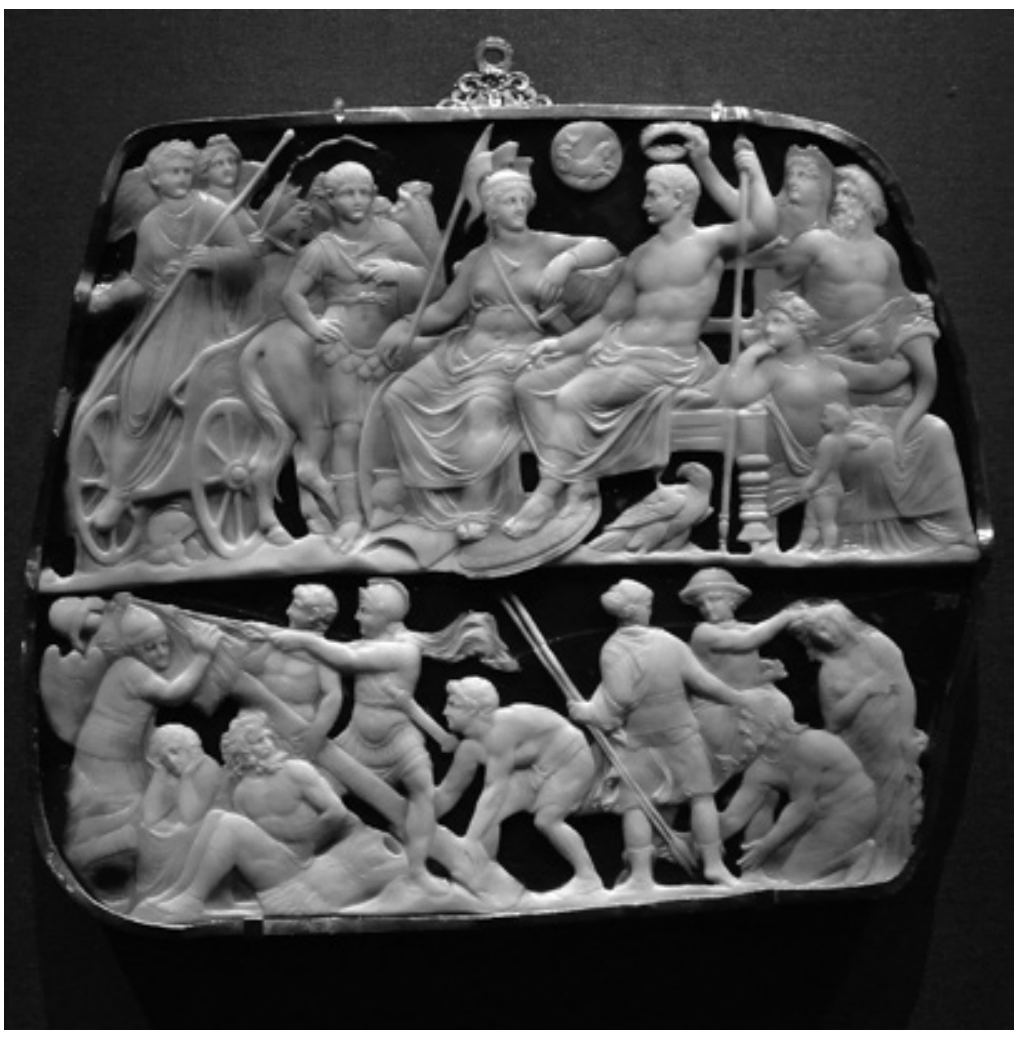

Fig. 4. Gemma Augstea, Første årtier af 1 . århundrede. Kunsthistorisches $\mathrm{Mu}$ seum, Wien 
(195). Denne orden er universel, forklarer brystpanserets ikonografi, og den er tidløs, ligesom himmellegemernes cyklus og skønhedsidealets ophøjethed. Den ophøjede krop gør krav på at være "alt i alle" (cf. 1 Kor 15,28), og dens kvasi-guddommelige fremtræden udgør det modsatte af tilsynekomsten af sårmærker i Paulus' kød.

Selv om der i hvert fald indledningsvis har været tale om, at man i den vestlige del af romerriget anså sådanne fremstillinger for at være symbolske fremstillinger af kejserens person, bredte Augustus-kulten - og den efterfølgende kejserkult - sig hastigt, og befordret af traditionen for herskerkult i de østlige dele af riget blev kejserens person tillagt guddommelighed (Zanker 1989, 294-5). Elsner er således ikke i tvivl om, at Augustus Prima Porta på én gang er en fremstilling af en person og en gud (Elsner 1995, 169). Zanker peger selv på den ny kunsts apoteotiske grundtone: På den såkaldte Gemma Augustea (fig. 4) troner Augustus som Jupiter med ørnen ved siden af Roma, mens Okeanos og Oikoumene flankerer tronen. Indledningsvis har denne type fremstillinger været betragtet som allegoriske "prædikater" til princeps' person, men med kejserdømmets etablering fik de hastigt en mere bogstavelig karakter: Kejseren var en gud, ligesom Jupiter (Zanker 1989, 238-9).

Hermed har jeg peget på en analogi. Figurer som Augustus Prima Porta udgør et tvedelt legeme, hvor Augustus' glansfulde, guddommelige krop kommer til syne igennem den historiske persons legeme. Det undergår derved en forvandling, som minder om den, som Paulus mener er påbegyndt med kødets hendøen, og som fuldendes, når de genopstandne ikke længere bærer det jordiske menneskes billede, men det himmelskes. Spørgsmålet er da, om der - ud over denne analogi - findes nogen yderligere grund til at antage, at den legemlige glans, som Paulus taler om i 1 Kor 15 svarer til den, som manifesterer sig i Augustus' ophøjede legeme?

Forvandlingsmotivet hos Ovid og hos Paulus

For at få øje på dette aspekt er det i første omgang nyttigt at genlæse 15,36-38. Selv om den "botaniske" redegørelse for frøets forandring til plante placeres inden for et kosmologisk system, hvor forskellen på jordiske og himmelske legemer følger samme love som forskellen på frø og planter og derfor kan forklares ved hjælp af samme "videnskabelige" principper (cf. Engberg-Pedersen 2009, 126), kan i hvert fald dette delafsnit af 15,35-41 læses som en lignelse, hvis lighed med re- 
elle forhold påpeges med v. 42a: "Således også de dødes opstandelse" (cf. Thiselton 2000, 1279).

Motivet med plantens vækst efter en forudgående forms hendøen er ligesom brugen af en lignelse til illustration af selve forvandlingsforløbet en topos i Ovids Metamorfoser, som i sit fokus på forvandlingen kredser omkring samme ontologiske "problem" som anden del af 1 Kor 15: Hvad er forholdet mellem det, som forvandles under en metamorfose, på den ene side og det, som forbliver identisk på den anden? ${ }^{14}$

Forvandlingerne i Metamorfoser foregår inden for forskellige kategorier, eksempelvis menneske til dyr (og omvendt), menneske til sten (og omvendt) og menneske til plante. Forvandlingerne af Dafne til laurbærtræet (Ovid 1984, I,548ff.) og Myrrha til træet, som bærer hendes navn (X,488ff.), indebærer i begge tilfælde, at personen, som forvandles, ophører at være den, hun er, men at hun transformeres på en sådan måde, at hendes identitet både bibeholdes og ophører med den nye forms opståen: Myrra-træet er stadig Myrrha, men i sin ny identitet som netop myrra-træet. Træet udgyder tårer (myrra), som fældes over grunden til hendes forandring $(X, 500) .{ }^{15} \mathrm{I}$ en stribe af motivisk beslægtede forandringer af personer, som dør, forvandles personen til en plante: Pyramus' forandres til morbærtræets bær (IV,158ff.), Hyacinthus til hyacinthen (X,162ff.), Adonis til sin blomst (X,708ff.) og Narcissus til narcissen (III,402ff.). Der er ikke tale om plante- eller blomsterfrøs forvandlinger, men dog om et botanisk princip: "det, som du sår, gøres ikke levende, hvis ikke det dør" $(15,36)$. Med det, der dør, "sås" en ny art i disse fortællinger.

Det er karakteristisk for fremstillingsformen i Metamorfoser, at Ovid ofte lader sin beskrivelse af en forvandling foregribe af en lignelse, hvor elementer i fortællingen skildres ved hjælp af former eller optrin, som er forskellige fra dem, som selve beskrivelsen angår. Ved at handlingen på denne måde transformeres, bliver lignelsen i sig selv en (litterær) metamorfose. Som Marie Louise Glinski har påpeget, fastholder lignelsen netop det spændingsforhold mellem identitet og forandring, som findes i en metamorfose, for lignelsen præsenterer en fremtrædelsesform, som adskiller sig fra det, som den ligner, li-

14. Ifølge både Jorunn Økland og Troels Engberg-Pedersen et spørgsmål, som Paulus også søger at besvare med 15,35ff. Se Jorunn Økland, "Genealogies of the Self: Materiality, Personal Identity, and the Body in Paul's Letters to the Corinthians", Seim \& Økland (2009), 83-108 (94) samt Troels Engberg-Pedersen (2009), 128-9. 15. Cf. Joseph B. Solodow, The World of Ovid's Metamorphoses (Chapel Hill \& London: The University of North Carolina Press 1988), 183. For Ovid henvises til følgende udgave: Ovid, Metamorphoses I-II LCL 42-3, overs. Frank Justus Miller (Cambridge, Mass.: Harvard University Press 1984). 
gesom den forvandlede form hos Ovid både er en nyskabelse og en videreførelse af den forandredes identitet. ${ }^{16} \mathrm{Da}$ Hyacinthus slås ihjel, sammenlignes hans hovedkulds fald med blomsters, og der opstår dermed et identitets- og spændingsforhold mellem den reelle fortælling og lignelsen: Mennesket Hyacinthus forvandles i lignelsens form til en blomst, før han i virkeligheden er forvandlet, men under den virkelige forvandling forandres han rent faktisk til en blomst efter sin død. Lignelsen og den efterfølgende forvandling er således på én gang overensstemmende, dvs. identiske, og forskellige fra hinanden, på samme måde som den forvandlede på én gang er identisk med sit tidligere jeg og omdannet til noget nyt (Glinski 2012, 29-30). Det er denne fremstillingsform, der ses gentaget i Paulus' botaniske lignelse 15,36-38, hvor spørgsmålet om kroppens opstandelse i forvandlet form besvares.

I Metamorfoser indgår en række spredte apoteoser, hvis kulmination er guddommeliggørelsen af Julius Cæsar og omtalen af den forventede tilsvarende apoteose for divi filius, Augustus (Ovid 1984, XV,84370). Pointen med apoteosernes optræden blandt andre forvandlinger er selvfølgelig, at de tilhører samme kategori, dvs. metamorfoser slet og ret (Solodow 1988, 191). Ved Cæsars apoteose bæres hans ånd fra kroppen til himmels, hvor han bliver til en stjerne, og samme forvandling forventes at ske for Augustus' vedkommende. Klassiske filologer anser almindeligvis denne kulmination som indvarslet allerede i Metamorfosers første sang, hvor Jupiters optræden blandt guderne i en rådssal fremstilles som princeps' forsæde i det romerske senat, sådan at læseren genkender Augustus i Jupiters skikkelse. ${ }^{17}$ Apoteosens generelle sammenhæng med en forvandling, som indebærer en ydre, kropslig forandring til et mere glansfuldt legeme - i Cæsars og Augustus' tilfælde et himmellegeme - eksemplificeres i Herkules' apoteose (Ovid 1984, IX,211-72). Han aflægger sin dødelige "mors billede", men fastholder sin far, "Jupiters træk", "ligesom en slange, når den har aflagt sin gamle ham" (bemærk lignelsen), hvorefter hans "bedre del blomstrer", "begynder at tage sig mægtigere ud" (maiorque videri) og "gøres ophøjet" (augusta fieri).

Ovids Metamorfoser uddyber forbindelsen mellem Paulus' pneumatiske krop på den ene side og den guddommelige krop, som træder frem i Augustus Prima Porta på den anden. Hos Ovid tilhører den apoteotiske forvandling en generel forvandlingskategori, hvor én legemlig form afløses af en anden, og hvor én forms hendøen indebærer

16. Marie-Louise Glinski, Simile and Identity in Ovid's Metamorphoses (Cambridge: Cambridge University Press 2012), 2.

17. Thomas Habinek, "Ovid and Empire", The Cambridge Companion to Ovid, red. P. Hardie (Cambridge: Cambridge University Press: 2002), 51 (46-61). 
fremkomsten af en anden, som både fastholder den første forms identitet og er forskellig fra den. Lignelsen som topos i den ovid'ske forvandlingslære bruges også af Paulus i 15,36-38, hvor redegørelsen for den forestående forandring gives en anden skikkelse. Plantens erstatning af det "døde" frø findes hos Ovid som sammenknytningen af personers død med fremvæksten af nye plantearter. Det afgørende er her, at fremkomsten af et nyt, ophøjet legeme ved en apoteose ifølge Ovid svarer til disse typer forvandling. Hvis Paulus' forståelse af det himmelske menneskes billede følger tankemønstret i Metamorfoser, kunne det pågældende billede minde om det, som resulterer af guddommeliggørelsen, og det er netop det, vi præsenteres for i Augustus Prima Porta.

\section{Foran det nye billede: Beskuerens forvandling i henhold til Augustus' billede}

$\mathrm{Nu}$ er der imidlertid én væsentlig forskel på Paulus' redegørelse for karakteren af fuldbyrdelsen af den eskatologiske forvandling på den ene side og den guddommelige princeps' billede på den anden. Hvor Augustus Prima Porta fremstiller det forandrede legeme som ét, der alene tilhører Augustus, beskriver Paulus en forandring, som angår alle de korintiske kristne: De skal alle forvandles $(15,51)$ og ved denne forvandling komme til at bære det himmelske menneskes billede. Sagt med andre ord: Hvor Paulus tillægger alle kristne en egenskab af billede, først det jordiske menneskes, siden det himmelskes, synes Augustus-fremstillingen at udelukke sin romerske beskuer fra denne status. For hvor Augustus i sin barfodede, idealt klassicerende og symbolske fremtoning tydeligvis er et billede, vil den romerske betragter blot have kunnet iagttage sig selv som symbolsk repræsenteret i den universelle orden, som er præget på figurens brystpanser.

Jas Elsner har imidlertid indført et væsentligt korrektiv til en sådan forståelse af forholdet mellem Augustus og hans betragter. Han mener, at Zanker ved sin optagethed af skulpturens ikonografi og allusioner overser figurens implicitte påtvingelse af sin korporligt frembårne universelle orden på sin romerske beskuer. Som imperator træder Augustus frem mod beskueren og henvender sig til ham med en bydende gestus, der underbygges af den stilistisk og suggestivt guddommeliggjorte skikkelse. Ved at etablere et sådant imperativt forhold til betragteren, "opføres" et stykke af den verdensorden, som skildres på harnisket. Figuren fortæller ikke bare om sin ophøjethed gennem symbolik og allusioner; beskueren manipuleres desuden ind 
i en beskuerrelation til figuren, som forankres og underbygges af ikonografien. Forståelse af budskabet og tilegnelse - eller accept - af det hænger således sammen (Elsner 1995, 168). Resultatet af denne beskuerrelation er, at beskueren ser sig selv antage skikkelse gennem den figur, som træder frem imod ham. Beskueren opbygger et "billede" af sig selv, og ikke kun i metaforisk forstand, fordi han netop interagerer kropsligt med figuren. Med Elsners ord optræder beskueren her som "worshipper":

He or she is simply a human being in the face of eternity, a moving and impermanent being in the face of the statue's static permanence. The spectator is no longer a particular person, but a generalised exemplum of humanity (male or female) before the Divine (Elsner 1995, 172).

Hvor man hos Paulus i den eskatologiske situation forandres til det himmelske menneskes billede, er der foran Augustus Prima Porta ikke tale om omdannelse til gudens billede. Men der er tale om en omdannelse i henhold til gudens billede, som lader beskueren se sig selv på ny.

\section{Forvandling i henhold til billedet af herrens glans i 2 Kor 3,18}

Karakteren af den forvandling, som forudsiges i 15,49, fremstår en anelse mere præcist, hvis den jævnføres med den kortfattede beskrivelse af samme forvandlingsproces i 2 Kor 3,18: "Men vi alle med utilsløret ansigt, idet vi ser herrens glans som i et spejl, forvandles i henhold til dette billede, fra glans til glans, sådan som fra herrens ånd.” Omtalen af den manglende tilsløring falder her i forbindelse med Paulus' udlægning af Moses' tilsløring som markering af den gamle pagt $(3,12-13)$, og den er ikke relevant for selve forvandlingsproceduren, som jeg vil koncentrere mig om her, og som er versets hovedtema.

Skal verset forstås på baggrund af romersk visuel kultur, bør opmærksomheden rettes mod dels spejlbilledet som forbillede i forvandlingsprocessen, dels den karakter af efterligning, som de forvandledes omgestaltning former sig som. ${ }^{18}$ Begge aspekter hører hjemme i en

18. Min læsning af verset udgør en accentforskydning fra J.M.F. Heaths forståelse af forvandlingen som en åndelig forandring hos betragteren, der baserer sig på en "from" blikforvaltning, hovedsageligt forankret i jødiske visuelle fromhedsbegreber. I Heaths eksegese spiller spørgsmål om billede og mimesis en underordnet rolle, idet hun først og fremmest diskuterer forvandlingsbegrebet (Heath 2013, 175-225). 
fundamental romersk forståelse af, hvad et billede er, sådan som især Jás Elsner har påpeget det i adskillige studier. ${ }^{19}$ Både i billedkunst og inden for diskussionen af billeder var det en grundsætning, at billeder er mimetiske, dvs. at de efterligner den omverden, som romerrigets beskuere var fortrolige med, og at sigtet med billedfrembringelse overvejende er virkelighedstro gengivelser. Det er disse visuelle principper, der f.eks. er bærende for udsmykninger i romerske huse som dem, der findes i Herculanum og Pompeji, og som Elsner af samme grund har gjort til genstand for udbyggede fortolkninger (Elsner 1995, 51-84). Det er samtidig denne billedforståelse, der danner grundlaget for de kunsthistoriske anekdoter i Plinius d. Æ.s Naturhistorie, hvor berømte kunstneres bedrifter gentagne gange eksemplificeres ved deres værkers evne til at bedrage beskueren gennem overbevisende naturtroskab. ${ }^{20}$ Inden for denne billedforståelse finder spejlet sin plads som illusionismens bedste manifestation: Spejlbilledet er nemlig den perfekte efterligning af sit motiv, og betagelsen af spejlbilledets fuldkomne illusionisme finder udtryk i Narcissus' forgabelse i sin egen spejling i vandspejlet, sådan som det ses i vægmalerier fra tidlig kejsertid. ${ }^{21}$

Det er værd at bemærke, at det mimetiske princip går ud på, at kunsten efterligner naturen. Under et billedes tilblivelse gengives dets motiv så nøjagtigt som muligt, og i denne proces udgør virkeligheden, dvs. det som gengives, forlæg og forudsætning for billedet, altså efterligningen.

Den eskatologiske forvandling ifølge Paulus vender dermed denne billedforståelse på hovedet. Den kristne gestaltes ganske vist som en efterligning, men ikke som efterligning af et (virkeligt) motiv, snarere som efterligning af noget som allerede er et billede. Denne sondring svarer til en distinktion i Ovids Metamorfoser, hvor både en gængs mimesisforståelse og en undergravning af den finder sted. Forvandlingerne hos Ovid har karakter af en permanent forandring, hvor den skikkelse, som en person forvandles til, udtrykker den forvandledes identitet, situation eller relation, sådan som denne allerede forelå før selve forvandlingen, men nu foreligger i en forvandlet skikkelse. Vi så bl.a., at Myrrhas sorg over sin incestuøse relation til faderen vide-

19. Det gælder således både Elsner 1995 og artikelsamlingen Roman Eyes. Visuality and Subjectivity in Art and Text (Princeton \& Oxford: Princeton University Pres 2007). Se i øvrigt note 1.

20. F.eks. Pliny, Natural History IX LCL 394, overs. H. Rackham (London: William Heinemann 1968), XXXV, 36, 65.

21. Jás Elsner, "Viewer as Image. Intimations of Narcissus" (Elsner 2007), 132-76; Rabun Taylor, The Moral Mirror of Roman Art (Cambridge: Cambridge University Press 2008), 72. 
reføres og ses i myrratræet, og at Apollons begær efter Dafne videreføres og udtrykkes i hans tætte forhold til laurbærtræet, nu hvor det er blevet hans symbolske attribut. På samme måde anskueliggøres Arachnes beskæftigelse som væver i hendes forvandlede skikkelse som edderkop, der frembringer edderkoppespind, hvor hun selv har vævet billedtæpper (VI,129ff.). Ifølge Joseph B. Solodow er denne egenskab ved forvandlingen et ledemotiv i Metamorfoser, som præciserer et menneskes eller en genstands iboende egenskaber ved i en forvandlet skikkelse at lade dem træde frem som anskuelige tegn. Kendetegnende egenskaber udmøntes "away from the uncertain flux of experience towards the surface of clarity given by metamorphosis" (Solodow 1988, 197). I fortællingen om tyrannen Lycaon, der som straf for sine forbrydelser forvandles til en ulv, kommer hans vildskab således til udtryk i ulvens dyriske fremtoning (I,199ff. Solodow 1988, 175).

Metamorfosen hos Ovid er derfor en fremstilling af et motiv, nemlig den identitet eller det sagsforhold, som den åbenbarer. Solodow mener, at Ovid selv ekspliciterer dette: "A key term in the coinciding vocabularies of art and metamorphosis is imago, 'image' or 'representation.' The frequency with which it is used of the results of metamorphosis indicates how strongly Ovid felt them to be like works of art" (Solodow 1988, 205). Forvandlingens anskueliggørelse går altså ud på, at den forvandlede som imago synliggør, hvad der karakteriserer ham eller hende. Ovid betragter således Lycaons forvandlede skikkelse som et vellignende "billede af vildskab" (feritatis imago, I,239), og efter Adonis' død lover hans elskerinde, Venus, rituelle fester hvert år - de såkaldte adonia - som sammen med hans blomst skal fremstille hans skikkelse og endeligt som "mindesmærker" og "billede" (monumenta [...] repetitaque imago, X,725ff.). Som Solodow pointerer, falder dette syn på billedets funktion i tråd med den græsk-romerske forestilling om mimesis (Solodow 1988, 209). Billedet fungerer her som en illusionistisk fremstilling af sit motiv, for Lycaon er virkelig så vild, som han ser ud, og den rituelle sørgefest for Adonis er - ligesom hans blodrøde blomsts korte levetid - en adxkvat fremstilling af sit forlæg. Det er dette kunstsyn, der kondenseres i fortællingen om billedhuggeren Pygmalion, som forelsker sig i sin elfenbensskulptur, hvis livagtighed han forveksler med virkelighed (X,243ff.), for "i dén grad skjuler kunsten sig i sin kunst" (X,252).

Solodow og Marie Louise Glinski har dog begge gjort opmærksom på, at denne billedopfattelse komplementeres af en modsatrettet tendens i Metamorfoser. I en række tilfælde har kunsten ikke status af efterligning af naturen, men omvendt: Drengen Adonis ser ud ligesom "nøgne amoriners kroppe males på malerier" $(\mathrm{X}, 516)$, mens 
Andromeda og den forstenede Narcissus sammenlignes med statuer (IV,675; III,418f.). Sådan synliggøres de pågældende figurers karakter ud fra kunstens fremstillingsprincipper (Solodow 1988, 213). Ved menneskenes genskabelse efter syndfloden skildrer Ovid deres tilsynekomst som en fremstilling af træk ved de sten, som de forvandles fra: Deres jordlignende og fugtige dele bliver til væv, mens hårdere dele bliver til skelet, og årerne i stenene bliver til kredsløbets årer (I,400ff.). Ovid betoner, at denne forvandling svarer til, når en billedhugger frembringer et menneskes skikkelse af marmorblokkens dvs. stenens - udseende og sammensætning, og pointen er således at menneskets skabelse svarer til kunstnerens frembringelse af sit værk, sådan at naturen imiterer kunsten (Glinski 2012, 35).

I Metamorfoser finder vi derfor både en traditionel mimesis-tænkning, hvor der lægges vægt på billedets illusionistiske karakter, og et korrektiv til denne tankegang, hvor mimesis drejer sig om efterligning af noget, som allerede er et billede. Dette korrektiv svarer til budskabet i 1 Kor 15,49 samt 2 Kor 3,18, hvor Paulus beskriver den eskatologiske forvandling som en omgestaltning i henhold til et billede. Indholdet af de to pågældende vers i korinter-korrespondancen stemmer i øvrigt overens med Paulus' betoning af mimesis som princip $i$ forbindelse med omgestaltningen af menigheden af $i$ Thessalonika i 1 Thess 1,6-7, hvor han minder læserne om menighedsmedlemmernes rolle som efterlignere ( $\mu$ í $\left.\mu \eta \alpha_{\imath}\right)$ af Paulus selv og som forbillede (тú тоv) for andre omvendte. Paulus' argumentation indskriver sig her i den romerske visuelle kulturs mimetiske vaneforestillinger, dvs. netop de visuelle vaner, som genfindes i 1 Kor 15,49 og 2 Kor 3,18 - uanset forskellen på den eskatologiske begivenhed, som skildres i de pågældende passager i brevene til henholdsvis Thessalonika og Korinth. ${ }^{22}$

22. J.M.F. Heath har påpeget, at Paulus i 1 Thess gør brug af en henvendelsesform, som er knyttet til enargeia som princip i antik retorik. Formålet med denne form er at gøre talerens forestillinger - og i 1 Thess taleren selv - nærværende og livagtige for den lyttende, og Heath nævner selv forbigående, at enargeia derved svarede til andre mimetiske kunstarter som billedkunst og poesi, men hun redegør ikke for forholdet til romersk visualitet. J.M.F. Heath, "Absent Presences of Paul and Christ: Enargeia in 1 Thessalonians 1-3", JSNT, 32, 1 (2009), 3-38 (4). Tilsvarende har Harry O. Maier peget på enkelte af passagerne i korinter-korrespondancen som præget af retoriske figurer, der skulle tjene til at fremmane forestillingsbilleder og derved havde tilknytning til romersk visualitet. Han undlader dog at knytte disse retoriske principper - og de relevante passager i brevene - til mimesis som en grundlæggende forestilling i romersk synskultur. Se Harry O. Maier, "Vision, Visualisation, and Politics in the Apostle Paul", Method and Theory in the Study of Religion, 27 (2015), 312-32 (320-22). 
Imitation og tvedelt legeme som visuelle vaner i 1 Kor 15,49

Når der ses på den tidlige romerske kejsertids visuelle konventioner og mimesisforståelse, findes der altså forudsætninger for at definere Paulus' - og hans læseres - forståelse af omtalen af den himmelskes billede i 15,49. For det første kan det slås fast, at der er overensstemmelse med den figurgengivelse, som ses i periodens kejserfremstillinger, og for det andet har forestillingen om forvandling i henhold til et billede en mimetisk kunstforståelse som en præmis, der i praksis rummer plads til sin modsætning. Selv om billedet efterligner naturen, kan efterligningen godt forme sig efter billedet.

I Augustus Prima Porta kan der iagttages en kropslig tvedeling, som svarer til, hvad der er på spil hos Paulus. Som jeg argumenterede for under inddragelse af Ovids Metamorfoser, kan princeps' ophøjede legeme ses som udmøntningen af et forvandlingsprincip, som hos Ovid indbefatter apoteosen. Denne iagttagelse er vigtig, fordi den peger på et slægtskab mellem Ovid og Paulus. Paulus' beskrivelse af forvandlingen svarer ved både sin brug af botanisk eksempelmateriale og brug af lignelsen som litterær forvandlingstopos til Ovids fremstilling af forvandlingen som princip. Dette bestyrker antagelsen af, at Paulus' pneumatiske krop kan forstås på baggrund af visuelle konventioner, som ses i Augustus Prima Porta. Hos Cicero, med hvis naturfilosofi Paulus' egen kosmologiske redegørelse i kap. 15 bærer fællestræk, beskrives det apoteoserede legeme desuden sådan, at det i særlig grad manifesterer æterens ild, dvs. det element, der svarer til det paulinske pneuma.

Ifølge 15,49 og 2 Kor 3,18 omformes den kristnes krop i imitation af et billede. En sådan idé er på spil i Augustus Prima Porta, hvor den portrætteredes legeme imiterer Polyklets Spydbereren, og princippet beskrives hos Ovid, hvor kroppens forvandling kan foregå som efterligning af kunst. Faktisk har Jás Elsner argumenteret overbevisende for, at billedkunstens ideale kejserlegeme indbefattede og forandrede sin betragter, som altså i overført forstand tog form efter dette billede.

Som arkæologen Christopher Hallett har bemærket, udgør kropslig tvedelthed et ledemotiv i helfigursportrætter i romersk skulptur. Hvor statuernes hoveder følger den romerske billedkunsts mimetiske principper og gennem portrætlighed foregiver at gengive de portrætteredes udseende og karakter, suppleres dette aspekt af en kropsfremstilling, som i øvrigt følger et idealiserende skema og på den måde lader to legemer sameksistere i samme figur. ${ }^{23}$ Hans iagttagelse sætter

23. Christopher H. Hallett, The Roman Nude. Heroic Portrait Statuary 200 BC$A D 300$ Oxford Studies in Ancient Culture and Representation (Oxford: Oxford University Press 2005), 277-97. 
fokus på en konvention inden for romersk visuel kultur, som selvfølgelig ikke er identisk med forestillingen om ét legemes hendøen og et andets opståen, men ikke desto mindre stimulerer ved sin åbenlyse sidestilling af to billedformer i samme figur. Paulus' læsere, som kendte til kejserfremstillinger og heroiske portrætter, må have næret bestemte forestillinger om, hvordan et ophøjet, pneumatisk legeme ser ud, fordi de kendte til billeder af det. 